\title{
Increasing Financial Health Stability Of Logistics Companies : A Thailand Case
}

\author{
Jaruwan Songsang*, Kamonchanok Suthiwartnarueput** Pongsa Pornchaiwiseskul***
}

\begin{abstract}
The purposes of this paper are 1) to develop model of long term financial health for logistics companies in Thailand 2) to identify factors that determine long term financial

stability. Many researchers currently provide factors affecting financial health. Most factors refer to financial ratios, not many non-financial ratios such as age and size have been mentioned. This paper considers both financial and non-financial ratios that affect financial performance of Logistics companies in Thailand. The study has covered some interesting non-financial ratios such as Nationality of Shareholders, type of network in Logistics Company, growth rate (consisted of sales growth rate/profit growth rate/asset growth rate / Liability growth rate) and variable of growth rates. The target group is 110 logistics companies in Thailand enlisted from Department of International Trade Promotion Ministry of Commerce, Royal Thai Government. The group is divided into three categories according to financial health of company; Healthy financial, Unhealthy (Distress) and normal situation. The Multidiscriminant Analysis (MDA) is applied to analyze the differentiations among the three categories. Significant variables from MDA will be used as the independent variables for Multimonial Logistic Regression Analysis (MLRA) to identify factors that determine long terms financial stability. This paper find CF/D, RE/TA, BE/TL, Size, Age, Type of network, Nationality of Shareholders and Number of Shareholders are significant factors determine long term financial stability of Logistics company in Thailand.
\end{abstract}

Keywords: Financial Health Stability, Variable of Growth Rate, Multidiscriminant Analysis, Multinomial Logistics Regression Analysis

Submission Date: 03/11/2015 Revision Date: 01/03/2016 Acceptance Date: 01/04/2016

* Logistics Management Programme, Chulalongkorn University, Bangkok, Thailand

Corresponding author, email address : shinjung1@hotmail.com

** Logistics Management Programme, Chulalongkorn University, Bangkok, Thailand

*** Faculty of Economics, Chulalongkorn University, Bangkok, Thailand 


\section{Introduction}

Thailand is recognized by the World Bank as "one of the great development success stories" in social and development indicators. Due to the geographical location which is an advantage to become a future logistics hub of South East Asia. Logistics is an important industry in Thailand as generating about 3\% of Thailand's GDP in 2008 and maintain between 2-3.5\% for the next several years (Office of the National economic and social development board -NESDB). In terms of logistics cost compare to GDP. Thailand cost is nearly $20 \%$ of GDP which is considered still high according to Bowersox, Rodrigues and Calantone (2005) While USA level is single digit. In order to improve logistics sector, the cost of logistics to be reduced and also to focus on the improvement in terms of performance.

The financial performance has been considered from researchers in many areas of business to identify the organization's health and its survival. High performance reflects management effectiveness and efficiency in making use of company's resources, and this, in turn, contributes to the country's economy at large. (Naser and Mokhtar, 2004)

In order to improve competency of logistics sector in Thailand, therefore this study aims to

1) develop model of long term financial health for logistics companies in Thailand

2) identify factors those determine long term financial stability.

According to Kim,et al. (2002) and Cho,et al.(1995) A combination of multiple models reduce the variance of estimated error and also improves the whole recognition performance also the mix improves the prediction accuracy and stability (Sun\&Lee (2008). This paper applies Multidiscriminant Analysis (MDA) and Multimonial Logistic Regression Analysis (MLRA) as tools where result will be mentioned in the result and analysis part of this paper.

\section{Literature Review}

Financial health designates how successful the company has been with money. There are many factors that need to consider when measure financial health. The prediction of financial distress is one of the tools to predict future financial health of the company. There have been many studies on the prediction of financial distress that will be described in this part. 


\subsection{Financial Health Studies}

The prediction of financial distress has been studied by many researchers during the last 70 years. The early researches (Ramser and Foster, 1931; Fitzpatrick, 1932; Winakor and Smith, 1935; Merwin, 1942) concentrated on the comparison of the financial ratios in failed and non-failed firms and concluded that the poorer ratios affected the failed firms. The change in research study by Beaver (1966). A pioneering study in the field is done by Altman (1968), who was the professor of New York University, developed his classic multivariate insolvency prediction model (using Multi discriminant Analysis - MDA) where variables are combined simultaneously to analyze financial distress. Altman found that his model is outperformed Beaver's ratios. Altman Z-score had been widely used by many studies for the last 40's years (von stein1968, Edmister1972, Deakin1972, Blum1974, Mader1975\&1977, Beerman1976, Moyer1977, Altman1977, Halderman \& Naarayanan1977, Collongues1977,bBilderbeek 1977\&1979, Weinrich's1978, Knight1979

Altman, Baidya and Riberio-Dias1979, Gebhardt1980, Bontemps1981, Ko1982, Altman1983, Booth1983, Rose \& Giroux1984, Casey \& Bartczak 1985, Lawrence \& Bear1986, Poston1994, Harmon, \& Gramlich1994, Grice \& Ingram2001, Arindam Bandyopadhyay2006, M. Kannadhasan2007, Qian Guo-ming,et al.2007, Alkhatib, K., \& Al Bzour2011, Obaid Saif H. Al Zaabi2011)

Even though MDA performed high accuracy but is limited to binary dependent variable (Ohlson, 1980) and does not indicate the probability of firm's financial distress (Nam\& Jinn, 2000). Ohlson (1980) used econometric methodology of conditional Logistics Analysis for nonlinear regression models where the probability of the firm's financial predictors fall between 0 and 1 many studies applied Logistics Regression into financial health (Desai,et al.1997, Collins \& Green1982, Ingram \& Frazier1982, Hamer1984, Harrel \& Lee1985, Gentry,et al.1985, Lo1986, Zmijewski1988, Kamakura1988, Gessner1988, Malhortra1988, Luther1998, Mine U ggurlu 2006, Han Donker2009, Nicolas Emanuel Monti2009, Angela Chih-Ying Christidis,et al.2010, Nataša Šarlija2011, Mohd Norfian Alifiah,et al.2012). Apart from Logit analysis, Zmijewski (1984) used a probit approach with his model in financial prediction also Yobas,et al.2001. Since the computer capabilities had been developed, Neural Network was conducted using complex relationship of mathematic by Etheridge \& Sriram(1997). There are also other tools have been applied in the financial study such as Hazard models by Shumway(2002) and "BlackScholes-Merton option pricing model. (BSM)" by Hillegeist,et al.(2004). 


\subsection{Variables}

From literature Reviews, there have been no exactly variables that fully influence financial health, therefore this study classifies variables into 2 groups; namely

1) Financial Variables

2) Non-Financial Variables

\subsubsection{Financial Variables}

The variables concerning financial data calculated from financial statement documents which are not only financial ratios will be included in financial variables but also growth rate and variation of growth rate will be considered in this study.

\subsubsection{Financial Ratio Variables}

There are four main groups of significant financial ratios as follow;

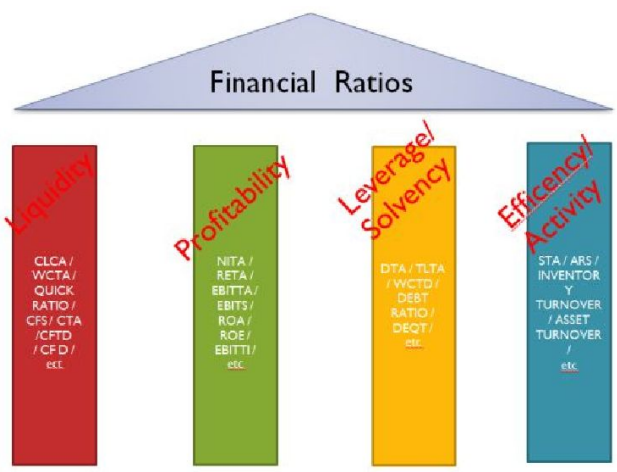

Figure 1.

Financial Ratios

1. Liquidity ratios : this ratios measures a firm's ability to pay short-term obligations. Healthy firm normally have high liquidity ratio.

2. Profitability ratio : this ratios show a firm's ability to generate profits from its expenses and other relevant costs incurred during a specific period of time. Healthy firm normally have high profitability ratio 
3. Leverage or Solvency ratio : this ratios measure firm's capacity to meet its long-term financial commitments. Healthy firm usually poses adequate leverage.

4. Efficiency or Activity ratio : measure a firm's effectiveness of the firm's use of its resources (assets, leverage, liabilities or other such balance sheet items). Healthy firm normally have high efficiency or activity ratio.

\section{Table 2-1.}

\section{Summary of financial ratios variable with formular and reference}

\begin{tabular}{|c|c|c|c|}
\hline $\begin{array}{c}\text { Financial Ratio } \\
\text { Variables }\end{array}$ & Ratio & Formular & Reference \\
\hline \multirow[t]{11}{*}{ Liquidity ratios } & CACL(Current ratio) & Current assets/current liabilities & $\begin{array}{l}\text { Shuk-Wern Ong (2011), Altman and Lavallee } \\
\text { (A\&L), (1981)). }\end{array}$ \\
\hline & SHCTA (Quick ratio) & short term liabilities-share holder capital/Total assets & Laitinen, 2005 \\
\hline & CLCA & Current liabilities/Current assets & $\begin{array}{l}\text { Altman ,1977), Ohlson,(1980), Betts and Belhoul } \\
\text { (1987 }\end{array}$ \\
\hline & CFA & $\begin{array}{l}\text { (Cash flow to assets - Earnings before interest, taxes, } \\
\text { depreciation and amortization) - (EBITDA)/total } \\
\text { assets }\end{array}$ & Shuk-Wern Ong, 2011 \\
\hline & CFD & (Cash flow to total debt) - EBITDA/total liabilities & $\begin{array}{l}\text { Shuk-Wern Ong (2011), Beaver(1966), Von stein } \\
\text { (1968), Beerman (1976), Laitinen (2005) }\end{array}$ \\
\hline & CTS & Cash flow to sales & Laitinen $(2005$ \\
\hline & CTA & Cash flow/Total assets & Arindam Bandyopadhyay (2006) \\
\hline & WCTA & Working capital/total asset & $\begin{array}{l}\text { Altman(1968, 1977), Altman, Baidya and Riberio- } \\
\text { Dias (1979), Ohlson (1980), Altman, Hatzell and } \\
\text { Peck (1995), Hillegeist et al. (2004), Arindam } \\
\text { Bandyopadhyay (2006) }\end{array}$ \\
\hline & STDSTD & Short term $\operatorname{debt}(\mathrm{t}) /$ Short term $\operatorname{debt}(\mathrm{t}-1)$ & Van Frederikslust (1978) \\
\hline & EBTTD & - Earning before tax/Total debt & Altman and Lavallee (A\&L) 1981 \\
\hline & WCTD & Working capital/total debt & Chen and Shimerda (1981), Ko (1982) \\
\hline \multirow[t]{9}{*}{$\begin{array}{l}\text { Profitability } \\
\quad \text { ratio }\end{array}$} & NITA & Net income/total asset & $\begin{array}{l}\text { Beaver,(1966), Ohlson (1980), Betts and Belhoul } \\
\text { (1987) }\end{array}$ \\
\hline & $\begin{array}{l}\text { EBITTA ( Return on } \\
\text { asset) }\end{array}$ & Earnings before interest and tax (EBIT)/total asset & $\begin{array}{l}\text { Altman(1968, 1977), Altman, Baidya and Riberio- } \\
\text { Dias (1979), Altman, Hatzell and Peck (1995), } \\
\text { Hillegeist et al. (2004) }\end{array}$ \\
\hline & $\begin{array}{l}\text { RETA (Cumulative } \\
\text { profitability) }\end{array}$ & Retain earnings / total asset & $\begin{array}{l}\text { Altman (1968, 1977), Bilderbeek (1977, 1979), } \\
\text { Altman, Hatzell and Peck (1995) }\end{array}$ \\
\hline & $\begin{array}{l}\text { ROE (Return on } \\
\text { equity) }\end{array}$ & EBT/equity & Van Frederikslust (1978) \\
\hline & TECTA & Total equity-capital contributed by shareholders(CCS) & Altman, Baidya and Riberio-Dias (1979) \\
\hline & EBITS & EBIT/Sales & Ko (1982) \\
\hline & $\begin{array}{l}\text { CPTA (Cash profit } \\
\text { ratio) }\end{array}$ & ETA+depre+amortaization/Total assets & Arindam Bandyopadhyay (2006) \\
\hline & OPTA & operating profit/Total assets & Arindam Bandyopadhyay (2006) \\
\hline & NITL & net income/total liability & $\begin{array}{l}\text { Zmijewski (1984), Betts and Belhoul (1987), } \\
\text { Shumway (2001). }\end{array}$ \\
\hline \multirow[t]{8}{*}{$\begin{array}{l}\text { Leverage or } \\
\text { Solvency ratio }\end{array}$} & TLTA & Total liabilities/total assets & $\begin{array}{l}\text { Shuk-Wern Ong (2011), Beaver(1966), Altman and } \\
\text { Lavallee (A\&L) 1981 (11), Hillegeist et al. (2004) }\end{array}$ \\
\hline & MVEBVTL & Market value of equity / Book value of total liabilities & $\begin{array}{l}\text { Altman(1968), Altman, Baidya and Riberio-Dias } \\
\text { (1979) }\end{array}$ \\
\hline & BVETL & Book value of equity/total liabilities & Altman, Hatzell and Peck (1995) \\
\hline & Capitalization & 5 year avr equity/Toal capital & Altman 1977 \\
\hline & NPEQT & Net Profit/Equity & Bilderbeek 1977,1979 \\
\hline & TDTA & Total debt/Total assets & Beaver (1966), Altman and Lavallee (A\&L), 1981. \\
\hline & $\begin{array}{l}\text { TATB (Solvency } \\
\text { ratio) }\end{array}$ & TA/ total borrowings plus current liabilities and provisi & Altman and Lavallee (A\&L) , 1981. \\
\hline & WCTD & working capital/total dept DTA - Total debt/Total asse & Chen and Shimerda (1981), Ko (1982) \\
\hline \multirow[t]{12}{*}{$\begin{array}{l}\text { Efficiency or } \\
\text { Activity ratio }\end{array}$} & $\begin{array}{l}\text { SCA (Current asset } \\
\text { turnover) }\end{array}$ & Sales/current assets & Shuk-Wern Ong, 2011 \\
\hline & STA & Sales/total assets & $\begin{array}{l}\text { Shuk-Wern Ong, 2011, Altman, Baidya and } \\
\text { Riberio-Dias (1979), Altman and Lavallee (A\&L) } \\
1981\end{array}$ \\
\hline & DSR & Days sales in receivable - Receivables/(sales/365) & Shuk-Wern Ong, 2011 \\
\hline & INVTO & Inventory turn over ratio & von stein(1968),Beerman(1976), Ko(1982) \\
\hline & STENI & Standard error of Net Income & Ko, 1982 \\
\hline & MVEBVTL & equity market value/ book value total liability & Arindam Bandyopadhyay (2006) \\
\hline & AVTA & Added value/total assets & Bilderbeek 1977, 1979 \\
\hline & ARS & accounts receivable/sales & Bilderbeek 1977,1979 \\
\hline & FAG & fixed asset growth & Von stein $(1968$ \\
\hline & EGAG & Growth rate of equity - equity growth rate - asset grov & (Altman and Lavallee (A\&L) 1981 \\
\hline & LPHG & Low profitability/high growth rate & Laitinen (2005 \\
\hline & $\begin{array}{l}\text { SROA (Variation of } \\
\text { Growth) }\end{array}$ & stability of earning $=$ standard error of EBIT/TA & Altman (1977) \\
\hline
\end{tabular}


The below variables have not been raised by many studies but this paper is interested to find out whether they have any affect on long term financial health of the company.

\subsubsection{Other financial Variables}

There are not only financial ratios variable to be considered in this paper but also there are 2 groups of other financial variables included as follow.

- Growth Rate Variables.

Four cataglories of growth rates are in this study which is Sales growth (SG), Net profit growth (NPG), Total Asset growth (TAG) and Total liability growth (TLG).

-Variation of Growth Variables

In this study, variation of growths are considered in 4 aspects that are Variation of Sales growth (VSG), Variation of Net profit growth (VNPG), Variation of Total Asset growth (VTAG) and Variation of Total Liability growth (VTLG).

\subsubsection{Non-Financial Variables}

Apart from financial ratio which in general for theoretical points that considered as the significant factors in the prediction of distress situation, firm's growth and variation of firm's growth, it is worth to consider Non-Financial variable as well.

Even though the company is healthy but it's may not be sustainable which depends on many factors. This paper considers the following non-financial variables as one of the important group that might affect the stability of the financial health. They are;

\subsubsection{Company Age}

Old firm might have more experience, and benefit from reputation effects that might earn higher margin on sales. However, old firm might be inert and does routines which might make less profitability (Liargovas and Skandalis (2008). Therefore, age could be one of the factors affecting financial health of the companies. However, some literature are taking age of the firm from the variable due to a young firm probably show a low retained earnings/total assets (RETA) ratio because of no time to build up its cumulative profits (Altman, 2000). Therefore, it may be argued that the young firm is somewhat discriminated against in this analysis, and its chance of being classified as bankrupt is relatively higher than that of another older firm.

The age of the firm is often recognized as an important variable affecting the financial 
distress Keasey and Watson (1987) and Shumway (2001) have used age as a covariate in a financial distress model. Moreover, Laitinen (1992) has shown that the financial distress process may be different for young firms due to the lack of capital and cash flow generation. Argenti (1976) describes failure processes which are associated with the age of the firm. Also knight (1979) found that firm usually fails in early year in its life. Also many more researchers used this variable in their studies such as Argenti (1976), Laitinen (1992), Laitinen (2005) and Arindam Bandyopadhyay (2006).

\subsubsection{Company Size}

Size of the firm can influence the financial distress process (Altman, Halderman and Narayanan (1997), Ohlson (1980), Betts and Belhoul (1987). Keasey and Watson (1987),Shumway (2001), Turetsky and Mc Ewen(2001) and Laitinen (2005) have provided evidence on the significant of the size effect the firm health. However, a few studies considered company size as total asset (Altman,et al.1997, Ohlson,1980, Keasey and Watson,1987, Nittayakasetwat,1994, Laitinen,2005, Mine U ggurlu,2006, Han Donker,et al. 2009) or using total asset in logarithmic form. However, as logistics companies in Thailand consist of both asset based and non-asset based firms, size from this study used registered capital as the size of the company.

\subsubsection{Nationality of Shareholders}

From Thomsen, Steen; Pedersen, Torben, 1996, studied nationality and ownership structures on the 100 largest companies in six European nations (Denmark, France, Germany, Great Britain, the Netherlands and Sweden) where found that no indication that ownership modes systematically effect company performance in terms of growth and profitability. Ownership dispersion is not associated with better performance. Nieves Lidia Díaz-Díaz1 el at (2008) found out that no significant between the innovation of foreign-owned firms and that of domestically owned firms. However, the percentage of foreign ownership of Logistics Company in Thailand is increased from $49 \%$ in 2008 to $70 \%$ in 2010 (Chackrit Duangphastra,2011). This means the financial result of the company is attractive to foreigner to invest in Logistics companies in Thailand. Therefore Nationality of shareholder might affect financial performance.

\subsubsection{Type of Network}

There are a number of papers that proposed model of firm network/diversification to predict financial health by predicting firm bankruptcy. For example, Rose (1992) proposed 
managers to diversify their firm to different business in order to reduce the risk of bankruptcy (distress). Beaver,et al. (2005) proposed that large firms have a smaller probability of bankruptcy and that related to corporate diversification more than smaller one and those diversification and firm-size are two factors that may help to predict future financial health of the firm."

\subsubsection{Number of shareholders}

The number of shareholders increase, might have more conflict between shareholders and other parties in the firm that might caused firm unhealthy. Whereas Family owned firm with less shareholders might have less conflict among shareholders that easily manage firm to become healthy. On the other hands, more shareholders might have more good idea where benefit to the firm. This study would like to find out if the number of shareholders are concerning financial health of the firm or not.'The more shareholders might have more conflict to the corporation that might casued firm unhealthy. Where as Family owned firm with less shareholders might have less conflict among shareholder that make corporation easily manage to become healthy. On the other hands, more shareholders might have more good idea where benefit to the firm. This study would like to find out if the number of shareholders are concerning financial health of the firm. 
Table 2-2.

Summary of significant variables from previous studies of the bankruptcy prediction.

\begin{tabular}{|c|c|c|c|c|c|c|c|c|c|}
\hline \multirow{4}{*}{ Researchers } & \multicolumn{9}{|c|}{ Variables } \\
\hline & \multicolumn{6}{|c|}{ Financial Variables } & \multirow{2}{*}{\multicolumn{3}{|c|}{$\begin{array}{c}\text { NON Financial Variables } \\
\text { NON Financial Ratios } \\
\end{array}$}} \\
\hline & \multicolumn{4}{|c|}{ Financial Ratios } & \multicolumn{2}{|c|}{ Other Financial Variables } & & & \\
\hline & Liquidity & Profitability & Solvency/Leverage & Efficiency/Activity & Growth Rate & Variation & Company age & Company size & Network \\
\hline \multirow{2}{*}{ Beaver (1966) } & & & & & & & & & \\
\hline & CFD & NITA & TDTA & & & & & & \\
\hline \multirow[b]{2}{*}{ Altman (1968) } & & RETA & MVEBVTL & STA & & & & & \\
\hline & WCTA & EBITTA & & & & & & & \\
\hline \multirow[b]{2}{*}{ von stein (1968), Beerman (1976) } & & & & & & & & & \\
\hline & CF & & & INVTO & FAG & & & & \\
\hline & & & & & & & & & \\
\hline Argenti (1976) , Knight (1976) & & & & & & & Y & & \\
\hline \multirow[b]{2}{*}{ Altman (1977) -28 } & & RETA & EBITTI & & & & & & \\
\hline & CACL & EBITTA & EQTTC & & & SROA & Y & & \\
\hline & & & & & & & & & \\
\hline \multicolumn{10}{|l|}{ Altman, Haldema and Naray(1977) } \\
\hline $\begin{array}{l}\text { Bilderbeek }(1977,1979) \text { The } \\
\text { Netherland(5/20) }\end{array}$ & & & & AVTA & & & & & \\
\hline & & RETA & NPEQT & STA, ARS & & & & & \\
\hline & & & & & & & & & \\
\hline Van Frederikslust (1978) The Netherlan & STDSTD-1 & ROE & & & & & & & \\
\hline & & EBITTA & & & & & & & \\
\hline Altman, Baidya and Riberio-Dias (1979) & WCTA & TECTA & MVEBVTL & STA & & & & & \\
\hline & FUTL & CHIN & & & & & & & \\
\hline Ohlson (1980) & WCTA, INTWO & NITA & TLTA & & & & & $Y(\log ($ TA/GDPindex $))$ & \\
\hline $\begin{array}{l}\text { Altman and Lavallee (A\&L) } 1981 \text { (11) } \\
\text { canada }\end{array}$ & CACL & & TATB & & & & & & \\
\hline & EBTTD & & TDTA & STA & EGAG & & & & \\
\hline & & & MVETD & & & & & & \\
\hline Chen and Shimerda (1981) & & & WCTD & & & & & & \\
\hline & & & MVETD & STENI & & & & & \\
\hline Ko (1982) & & EBITS & WCTD & INVTO & & & & & \\
\hline & & & & & & & & & \\
\hline El Hennawy and Morris (1983) & & & & & & & & & \\
\hline Zmijewski (1984) & & & & & & & & & \\
\hline & CACL & NITL & & TLTA & & & & & \\
\hline & & & TLTA & & & & & & \\
\hline Betts and Belhoul (1987) & & NITL & & & & & & & \\
\hline & & & & & & & & & \\
\hline Keasey and Watson (1987) & & & & & & & & Y & \\
\hline & & & & & & & & & \\
\hline Platt and Platt (1990) & & & & & & & & & \\
\hline & & & & & & & & & \\
\hline Laitinen (1992) & & & & & & & Y & & \\
\hline & & RETA & & & & & & & \\
\hline Altman, Hatzell and Peck (1995) Mexico & WCTA & EBITTA & BVETL & & & & & & \\
\hline vaney (1998) & & & & & & & & & \\
\hline & & & & & & & & & \\
\hline & & & TLTA & & & & & & \\
\hline Shumway (2001) & & NITL & & & & & & Y & \\
\hline & & & & & & & & & \\
\hline Turetsky and Mc Ewen(2001) & & & & & & & & & \\
\hline Hillegeist et al. (2004) & & & & & & & & & \\
\hline & WCTA & EBITTA & TLMTA & & & & & & \\
\hline Laitinen (2005) & CFD, CFS, CTS & NPS & & & & & & & \\
\hline & STLTA, SHCTA & & & & LPHG & & Y & Y & \\
\hline & & CPTA & TATB & & & & & & \\
\hline Arindam Bandyopadhyay (2006) India & WCTA & OPTA & MVEBVTL & STA & & & y & & Y \\
\hline & & EBITPC, ROE & FASE & STFA & & & & & \\
\hline Mine U ggurlu (2006) Turkey & & EBITTD, EBITS & SETA, LTDTD & OIBOIA.SETA.TOAS & & & & $Y$ & \\
\hline $\begin{array}{l}\text { Han Donker , Bernard Santen \& Saif } \\
\text { Zahir (2009) The Netherland }\end{array}$ & & & & & & & & & \\
\hline & CFTA & & BVTDBVTA & PAYOUT & & & & Y & \\
\hline & CLCA, FUTL & EBITA & RETA, MVETL & STA & & & & & \\
\hline Y.Wu (2010) & WCTA, INTWO & NITA, CHIN & TLTA,OENEG,TLMTA & & & & & $Y$ & $\mathrm{Y}$ \\
\hline & & & TLTA & DSR & & & & & \\
\hline Shuk-Wern Ong (2011) & CFD & & & SCA, STA & & & & & \\
\hline
\end{tabular}




\begin{tabular}{|c|c|c|c|}
\hline WCTA & $=$ working capital/total assets & FAG & $=$ fixed asset growth \\
\hline CFD & $=$ cash flow $/$ debt & SROA & $=$ stability of return on assets \\
\hline NITA & $=$ net income/total assets & EGAG & $=$ equity growth rate - asset growth ra \\
\hline TDTA & $=$ total debt/total assets & LPHG & $=$ Low profitability/high growth rate \\
\hline RETA & $=$ retained earning/total assets & & (The growth of the firm = annual perce \\
\hline $\begin{array}{l}\text { EBITTA } \\
\text { CF }\end{array}$ & $\begin{array}{l}=\text { earning before interest and tax/total assets } \\
=\text { cash flow }\end{array}$ & & $\begin{array}{l}\text { while the return on investment and th } \\
\text { measure profitability) }\end{array}$ \\
\hline INVTO & $=$ inventory turn over & SHCTA & $=$ shareholder capiotal to total assets \\
\hline EQTTA & $=$ equity/total capital & WCLTD & $=$ Net working capital/long term debt \\
\hline FUTL & $=$ fund from operation/total liability & EBITTD & $=$ earning before interest, tax/total del \\
\hline WCLTD & $=$ working capital/long term debt & STFA & $=$ sales $/$ net tangible assets \\
\hline CACL & $\begin{array}{l}=\text { current ratio, currrent assets/ } \\
\text { current liability }\end{array}$ & $\begin{array}{l}\text { LTDTD } \\
\text { FASE }\end{array}$ & $\begin{array}{l}=\text { long term debt/total debt } \\
=\text { fixed assets/shareholders' equity }\end{array}$ \\
\hline CCL & $=\mathrm{cash} /$ curren liability & TOAS & $=($ Total assets $/ 1000) /$ wholesale price \\
\hline EBITTI & $\begin{array}{l}=\text { earning before interest and tax } / \\
\text { total interest payment }\end{array}$ & $\begin{array}{l}\text { SETA } \\
\text { OIBOIA }\end{array}$ & $\begin{array}{l}=\text { book value of equity/book value of } \mathrm{t} \\
=\text { other income before taxes/other inar }\end{array}$ \\
\hline NPEQT & $=$ net profit/equity & BVTDBVTA & $=\%$ of book value of total debt/book \\
\hline AVTA & $=$ added value/total assets & CFTA & $=\%$ chang in cash flow $/$ book value of \\
\hline ARS & $=$ account receivable/sales & PAYOUT & $=\%$ total dividen $/$ net income \\
\hline $\begin{array}{l}\text { STDSTD-1 } \\
\text { ROE }\end{array}$ & $\begin{array}{l}=\text { short term debt } \mathrm{t} / \text { short time debt } \mathrm{t}-1 \\
=\text { return on equity }\end{array}$ & CHIN & $\begin{array}{r}=\text { change in income })=(\text { NIt }- \text { Nit }-1) / \text { IN } \\
\text { where NIt is net income for the mos }\end{array}$ \\
\hline TLTA & $=$ total liability/total assets & OENEG & $=$ total liabilities exceed total assets \\
\hline EBTTD & $=$ earning before tax/total debt & DSR & $=$ days sales in receivable $=$ Receivabl \\
\hline STA & $=$ sales $/$ total assets & TECTA & $=$ (total equity-capital contributed by $\mathrm{s}$ \\
\hline WCTD & $=$ working capital/total dept & TATB & $=$ total assets/total borrowing plus curı \\
\hline MVETD & $=$ market value equity/total debt & & minus advance payment of tax \\
\hline STENI & $=$ standard error net income & MVEBV & $=$ equity market value/ book value \\
\hline NITL & $=$ net income/total liability & CPTA & $=$ cash profit $/$ total assets \\
\hline BVETL & $=$ book value equity/total liability & CFA & $=($ EBITDATA $)=$ earning before interes \\
\hline STLTA & $\begin{array}{l}=\text { short-term liquidity(shareholder capitaL)/ } \\
\text { to total assets }\end{array}$ & $\begin{array}{l}\text { SWC } \\
\text { SCA }\end{array}$ & $\begin{array}{l}=\text { sales/networking capital } \\
=\text { sales/current assets }\end{array}$ \\
\hline MVETL & $=$ market value of equity/total liability & SFA & $=$ Sales/BV of net tangible fixed assets \\
\hline OPTA & $=$ operation profit/total assets & EBITS & $=$ earning before interest/sales \\
\hline TATB & $=$ total assets $/$ total borrowings plus current liabilities a & EBITPC & $=$ earning before interest/paid capital \\
\hline MVEBV & equity/book value & $\begin{array}{l}\text { NPS } \\
\text { CTA } \\
\text { CTS }\end{array}$ & $\begin{array}{l}=\text { net profit/net sales } \\
=\text { cash flow/total assets } \\
\text { cash flow/sales }\end{array}$ \\
\hline
\end{tabular}

Most researchers have selected variable based on their popularity and predictive ability in the previous research studies. In this study, after a process of reducing the numbers of variables, the 10 financial ratios were selected based on the significance and most recognize of financial ratios in earlier studies. Other interesting financial variables that are Growth Rate, Variation of Growth Rate and 5 Non-Financial variables might significantly affect the stability of financial health of logistics companies in Thailand. Therefore total 23 variables are selected in this study that are;

Financial ratios

Liquidity ratios

CACL (Current ratio) - Current assets/current liabilities.

WCTA - Working capital/total asset

CFD (Cash flow to total debt) - EBITDA/total liabilities

Profitability ratio

NITA - Net income/total asset

EBITTA (Return on asset) - Earnings before interest and tax (EBIT)/total asset 
RETA (Cumulative profitability) - Retain earnings / total asset

NITL - net income/total liability

Leverage or Solvency ratio

TLTA - Total liabilities/total assets

BVETL - book value equity/total liability

Efficiency or Activity ratio

STA - Sales/total assets

Other financial variables

GW - Growth rate (consider sales growth rate, profit growth rate, asset growth rate and liability growth rate)

VGW - Variation of Growth Rate (consider variation of sales growth rate, variation of profit growth rate, variation of asset growth rate and variation of liability growth rate).

Non-financial Variables

Age - Company Age

Size - Company Size

Type of Network - Logistics Network/Non Logistics Network

$\mathrm{NSH}$ - Nationality of Shareholder (Thai/Non Thai)

NoS - Number of Shareholder

\section{Research Process and Methodology}

The paper employs two tools, namely

1) Multi discriminant Analysis

2) Multinomial Logistics Regression Analysis

The research plan is as follow.

\section{Part I}

The first part is to screen significant variables out of total 23 variables from 110 logistics companies, using data from 2009-2012. The Multidiscriminant Analysis tool (MDA) is employed in this part.

The multiple discriminant analysis models can be obtained with the following form:

$* Z_{L T i}=b_{0}+b_{1} X_{1 i}+b_{2} X_{2 i}+b_{3} X_{3 i}+\cdots+b_{k} X_{k i}$

Where $* Z_{L T i}=$ discriminant function score (Financial health level) of Logistics 
companies in Thailand,

$b_{0}=$ Constant,

$B_{j}=$ discriminant coefficients or weights; $j=1 \cdots, k$,

$X_{j}=$ predictors or independent variables.

The process of this research starts from categorise companies into three categories Financial Distress (Unhealthy)/ Normal and Non-distress (Healthy) and assigned value 0 to Unhealthy companies are assigned 1,2 to Normal companies and Healthy companies respectively.

The criteria of Unhealthy companies comprised of

Negative ROE (Du Pont), Negative net profits for two consecutive year and Negative Retained earnings for one year (Hu Gang ,2009).

The criteria of Healthy companies comprised of

Highest ROE (Du Pont), highest Net profits during the last two fiscal years and high Retained earnings.

The companies that are not in Unhealthy or Healthy group are considered as normal company.

Table 3-1.

Summary of groups

\begin{tabular}{c|c|c|c|c}
\hline & \multicolumn{3}{|c|}{ Groups } & \\
\hline Year & Distress Group(0) & Normal Group (1) & $\begin{array}{c}\text { Non Distress } \\
\text { Group(2) }\end{array}$ & Total \\
\hline 2009 & 25 & 60 & 25 & 110 \\
\hline 2010 & 21 & 68 & 21 & 110 \\
\hline 2011 & 23 & 64 & 23 & 110 \\
\hline 2012 & 25 & 60 & 25 & 110 \\
\hline
\end{tabular}

Since there are two groups of variables (18 Financial ratios variables and 5 Non-Financial variables), it is interesting to know whether there will be any differentiation or not between applying the total 23 variables and using data from Financial variables and Non-Financial variable separately would have the same result or not. Therefore, the 
analysis part are separated into two aspects, running the whole Financial Variables together with 5 Nonfinancial Variables(case 1) and running Financial Variables separately from Nonfinancial Variables(case 2).

The significant variables from part I will be the variables for part II

\section{Part II}

This part is to develop model of long term financial health for logistics companies in Thailand and to identify factors that determine long term financial stability by developing Multinomial Logistics Regression Analysis to significant variables from part I.

The Multinomial Regression Analysis models can be obtained with the following form:

Logit Response Function:

$$
\begin{aligned}
& g 0=L N\left(\frac{p 0}{p 1}\right)=\beta_{0}+\beta_{1} X_{1}+\beta_{2} X_{2}+\beta_{3} X_{3}+\cdots+\beta_{k} X_{k} \\
& g 2=L N\left(\frac{p 2}{p 1}\right)=\alpha_{0}+\alpha_{1} X_{1}+\alpha_{2} X_{2}+\alpha_{3} X_{3}+\cdots+\alpha_{k} X_{k}
\end{aligned}
$$

Where $g 0, g 2=\log$ odd or $\log i t$

$$
g 1=0
$$

$\pi_{j}(x)=\operatorname{Pr}(Y=j \mid x)=\frac{e^{g j(x)}}{{ }_{e} g o(x)+1+{ }_{e} g^{2}(x)}$

Where $j=0$ to $2 \cdots$

$\operatorname{Pr}=$ Probability to the outcome of the interest

$\sum_{j=0}^{2} \operatorname{Pr}(Y=j \mid x)=1$

This method will be applied to both case 1 and case 2 .

\section{Result and Analysis}

\subsection{Part I (Multi Discriminant Analysis)}

Case 1. Applying the total 23 variables (Financial Variables and Nonfinancial Variables) at the same time. 
Table 4-1.

Classification Function Coefficients for Total 23 Variables

\begin{tabular}{c|c|c|c}
\hline & \multicolumn{3}{|c}{ Distress/Normal/Non Distress } \\
\cline { 2 - 4 } & $\mathbf{0}$ & $\mathbf{1}$ & $\mathbf{2}$ \\
\hline CFD & 5.277 & 7.136 & 16.452 \\
\hline RETA & -1.414 & .603 & .795 \\
\hline NITL & -6.398 & -7.813 & -16.125 \\
\hline BVETL & -.038 & -.023 & -.355 \\
\hline Sales Growth & -.001 & .001 & .002 \\
\hline Variation of Net Profit Growth & .001 & .000 & .000 \\
\hline Size & .001 & .001 & .004 \\
\hline Nationality of shareholders & 2.822 & 2.411 & 1.662 \\
\hline (Thai/non Thai) & 1.016 & 1.208 & .914 \\
\hline No. of Shareholders & -6.702 & -6.294 & -5.198 \\
\hline (Constant) & & &
\end{tabular}

Fisher's linear discriminant functions

As per table 4-1, the multiple discriminant analysis function for running from all 23 Variables for 3 groups are as per below.

Distress group(Unhealthy)

$* Z_{A 110 i}=-6.702+5.277(\mathrm{CF} / \mathrm{D})-1.414(\mathrm{RE} / \mathrm{TA})-6.398(\mathrm{NI} / \mathrm{TL})-.038(\mathrm{BVE} / \mathrm{TL})-$ .001 (Sales Growth) +.001 (Variation of Net Profit Growth) +0.001 (Size) + 2.822(Nationality of shareholders (Thai/non Thai)) + 1.016 (No. of Shareholders)

Where $* Z_{A 110 i}=$ discriminant function score (Financial health level) of Logistics companies in Thailand (i) fall in group 0 ,

$b_{0}=$ Constant,

$B_{j}=$ discriminant coefficients or weights; $j=1 \ldots k$,

$X_{j}=$ predictors or independent variables.

Normal Group

$* Z_{A 111 i}=-6.294+7.136(\mathrm{CF} / \mathrm{D})+.603(\mathrm{RE} / \mathrm{TA})-7.813(\mathrm{NI} / \mathrm{TL})-.023(\mathrm{BVE} / \mathrm{TL})+$ .001 (Sales Growth) +0.001 (Size) +2.411 (Nationality of shareholders (Thai/non Thai)) +1.208 (No. of Shareholders) 
Where ${ }^{*} Z_{A 111 i}=$ discriminant function score (Financial health level) of Logistics companies in Thailand (i) falll in group 1 ,

$b_{0}=$ Constant,

$B_{j}=$ discriminant coefficients or weights; $j=1 \ldots k$,

$X_{j}=$ predictors or independent variables.

Non Distress Group (Healthy)

$* Z_{A 112 i}=-5.197+16.452(\mathrm{CF} / \mathrm{D})+.795(\mathrm{RE} / \mathrm{TA})-16.125(\mathrm{NI} / \mathrm{TL})-.355(\mathrm{BVE} / \mathrm{TL})$

+.002 (Sales Growth) +0.004 (Size) +1.662 (Nationality of shareholders (Thai/non

Thai) $)+.914$ (No. of Shareholders)

Where $* Z_{A 112 i}=$ discriminant function score (Financial health level) of Logistics companies in Thailand (i) fall in group 2,

$b_{0}=$ Constant,

$B_{j}=$ discriminant coefficients or weights; $j=1 \ldots k$,

$X_{j}=$ predictors or independent variables.

Among the 23 Variables, 8 variables of CFD, RETA, NITL, BVETL, Sales Growth, Size, Nationality of shareholders (Thai/non Thai) and No. of Shareholders are significant at the 0.05 level for all groups, meanwhile Variation of Net Profit Growth variable is significant at the 0.05 level for only Unhealthy group.

Case 2. Separate Analysis Financial Variables from Nonfinancial Variables.

Result from MDA for 18 Financial Variables is shown as follow.

\section{Table 4-2.}

Classification Function Coefficients for 18 Financial variables

\begin{tabular}{c|c|c|c}
\hline \multirow{2}{*}{} & \multicolumn{3}{|c}{ Distress/Normal/Non Distress } \\
\cline { 2 - 4 } & $\mathbf{0}$ & $\mathbf{1}$ & $\mathbf{2}$ \\
\hline CFD & -.167 & .549 & 2.833 \\
\hline RETA & -1.634 & .387 & .402 \\
\hline BVETL & .088 & .101 & -.076 \\
\hline Sales Growth & -.001 & .001 & .002 \\
\hline Variation of Net Profit Growth & .001 & .000 & .000 \\
\hline (Constant) & -2.718 & -1.369 & -1.970 \\
\hline
\end{tabular}


Fisher's linear discriminant functions

From table 4-2, the multiple discriminant analysis function from running 18 Financial Variables for 3 groups are as per below.

Distress group (Unhealthy)

$* Z_{F V 0 i}=-2.718-0.167(\mathrm{CF} / \mathrm{D})-1.634(\mathrm{RE} / \mathrm{TA})+.088(\mathrm{BVE} / \mathrm{TL})-.001($ Sales

Growth) +.001 (Variation of Net Profit Growth)

Where $* Z_{F V 0 i}=$ discriminant function score (Financial health level) of Logistics companies in Thailand (i) fall in group 0 ,

$b_{0}=$ Constant,

$B_{j}=$ discriminant coefficients or weights; $j=1 \ldots k$,

$X_{j}=$ predictors or independent variables.

\section{Normal Group}

$* Z_{F V 1 i}=-1.369+.549(\mathrm{CF} / \mathrm{D})+.387(\mathrm{RE} / \mathrm{TA})+.101(\mathrm{BVE} / \mathrm{TL})+.001($ Sales Growth)

Where ${ }^{*} Z_{F V 1 i}=$ discriminant function score (Financial health level) of Logistics companies in Thailand (i) falll in group 1,

$b_{0}=$ Constant,

$B_{j}=$ discriminant coefficients or weights; $j=1 \ldots k$,

$X_{j}=$ predictors or independent variables.

Non Distress Group (Healthy)

$* Z_{F V 2 i}=-1.970+2.833(\mathrm{CF} / \mathrm{D})+.402(\mathrm{RE} / \mathrm{TA})-.076(\mathrm{BVE} / \mathrm{TL})+.002($ Sales Growth)

Where ${ }^{*} Z_{F V 2 i}=$ discriminant function score (Financial health level) of Logistics companies in Thailand (i) fall in group 2,

$b_{0}=$ Constant,

$B_{j}=$ discriminant coefficients or weights; $j=1 \ldots k$,

$X_{j}=$ predictors or independent variables. 
Significant variables from MDA for Financial Variable are CF/D, RE/TA, BVE/TL, Sales Growth and Variation of Net Profit Growth.

Result from MDA for 5 Non Financial Variables is shown as follow.

Table 4-3.

Classification Function Coefficients for 5 Non Financial Variables

\begin{tabular}{c|c|c|c}
\hline \multirow{2}{*}{ Size } & \multicolumn{3}{|c}{ Distress/Normal/Non Distress } \\
\cline { 2 - 4 } & $\mathbf{0}$ & $\mathbf{1}$ & $\mathbf{2}$ \\
\hline Age & .000 & -.001 & .001 \\
\hline $\begin{array}{c}\text { Nationality of shareholders } \\
\text { (Thai/non Thai) }\end{array}$ & .129 & .193 & .207 \\
\hline $\begin{array}{c}\text { Type of Network } \\
\text { (Logistics / Non Logistics ) }\end{array}$ & 3.263 & 3.090 & 2.168 \\
\hline No. of Shareholders & .809 & 3.948 & 4.089 \\
\hline (Constant) & -6.342 & -8.308 & .584 \\
\hline
\end{tabular}

Fisher's linear discriminant functions

From table 4-3, the multiple discriminant analysis function from running Non-Financial Variables for 3 groups are as per below.

Distress group (Unhealthy)

$* Z_{N F 0 i}=-6.342+0($ Size $)+.129$ (Age) +3.263 (Nationality of Shareholders) +3.033

(Type of Network) +.809 (No. of Shareholders)

Where ${ }^{*} Z_{N F 0 i}=$ discriminant function score (Financial health level) of Logistics companies in Thailand (i) fall in group 0 ,

$b_{0}=$ Constant,

$B_{j}=$ discriminant coefficients or weights; $j=1 \ldots k$,

$X_{j}=$ predictors or independent variables.

Normal Group

$* Z_{N F 1 i}=-8.306-0.001($ Size $)+.193($ Age $)+3.090$ (Nationality of Shareholders) + 3.948 (Type of Network) +.885 (No. of Shareholders) 
Where ${ }^{*} Z_{N F 1 i}=$ discriminant function score (Financial health level) of Logistics companies in Thailand (i) fall in group 1,

$b_{0}=$ Constant,

$B_{j}=$ discriminant coefficients or weights; $j=1 \ldots k$,

$X_{j}=$ predictors or independent variables.

Non Distress Group (Healthy)

$* Z_{N F 2 i}=-6.608+0.001($ Size $)+.207($ Age $)+2.168$ (Nationality of Shareholders) + 4.089 (Type of Network) +.584 (No. of Shareholders)

Where ${ }^{*} Z_{N F 2 i}=$ discriminant function score (Financial health level) of Logistics companies in Thailand (i) fall in group 2 ,

$b_{0}=$ Constant,

$B_{j}=$ discriminant coefficients or weights; $j=1 \ldots k$,

$X_{j}=$ predictors or independent variables.

Significant variables from MDA for Non-Financial Variable are Size, Age, and Nationality of Shareholders, Type of Network and Number of Shareholders.

\section{Table 4-4.}

Summary of MDA result (Part I)

\begin{tabular}{|c|c|c|c|c|c|c|c|c|c|c|c|c|c|}
\hline \multirow[b]{2}{*}{ Variables } & \multirow[b]{2}{*}{ Groups } & \multirow{2}{*}{$\begin{array}{c}\text { Liquidity } \\
\text { Ratio }\end{array}$} & \multicolumn{2}{|c|}{ Profitability Ratio } & \multirow{2}{*}{$\begin{array}{c}\begin{array}{c}\text { Leverage } \\
\text { Ratio }\end{array} \\
\text { BVETL } \\
\end{array}$} & \multirow[t]{2}{*}{$\begin{array}{c}\text { Efficie } \\
\text { ncy } \\
\text { Ratio }\end{array}$} & \multirow[t]{2}{*}{$\begin{array}{l}\text { Sales } \\
\text { Growth }\end{array}$} & \multirow[t]{2}{*}{\begin{tabular}{|c|}
$\begin{array}{c}\text { Variation } \\
\text { of Net } \\
\text { profit } \\
\text { growth }\end{array}$ \\
\end{tabular}} & \multirow[t]{2}{*}{ Size } & \multirow[t]{2}{*}{ Age } & \multirow[t]{2}{*}{\begin{tabular}{|c|} 
Nationalit \\
y of \\
Sharehold \\
ers
\end{tabular}} & \multirow[t]{2}{*}{$\begin{array}{l}\text { Type of } \\
\text { Network }\end{array}$} & \multirow[t]{2}{*}{$\begin{array}{c}\text { No. of } \\
\text { sharehold } \\
\text { ers }\end{array}$} \\
\hline & & & RETA & NITL & & & & & & & & & \\
\hline \multirow{3}{*}{$\begin{array}{c}\text { All } 23 \\
\text { variables }\end{array}$} & Distress & 5.277 & -1.414 & -6.4 & -0.038 & & -0.001 & 0.001 & $1.00 \mathrm{E}-03$ & & 2.822 & & 1.016 \\
\hline & Normal & 7.136 & 0.603 & -7.81 & -0.023 & & 0.001 & & $1.00 \mathrm{E}-03$ & & 2.411 & & 1.208 \\
\hline & Non Distress & 16.452 & 0.795 & -16.1 & -0.355 & & 0.002 & & $4.00 \mathrm{E}-03$ & & 1.662 & & 0.914 \\
\hline \multirow{3}{*}{$\begin{array}{l}\text { Financial } \\
\text { variables }\end{array}$} & Distress & -0.167 & -1.634 & & 0.088 & & -0.001 & 0.001 & & & & & \\
\hline & Normal & 0.549 & 0.387 & & 0.101 & & 0.001 & & & & & & \\
\hline & Non Distress & 2.833 & 0.402 & & -76 & & 0.002 & & & & & & \\
\hline \multirow{3}{*}{$\begin{array}{c}\text { Non } \\
\text { Financial } \\
\text { variables }\end{array}$} & Distress & & & & & & & & $-3.89 \mathrm{E}-10$ & 0.129 & 3.263 & 3.033 & 0.809 \\
\hline & Normal & & & & & & & & $-9.03 E-10$ & 0.193 & 3.09 & 3.948 & 0.885 \\
\hline & Non Distress & & & & & & & & $7.86 \mathrm{E}-10$ & 0.207 & 2.168 & 4.089 & 0.584 \\
\hline
\end{tabular}

The study obtains significant variables from MDA to continue phase II.

\subsection{Part II (Multinomial Logistics Regression Analysis - MLRA)}

Case 1. Obtains 9 significant variables from MDA part I (case 1) that are $\mathrm{CF} / \mathrm{D}$, 
RE/TA, NI/TL, BVE/TL, Sales Growth, Variation of Net profit growth, Size, Nationality of Shareholders and No. of shareholders to MLRA. The parameter estimate are as follow.

\section{Table 4-5.}

Parameter Estimates From MLRA for 9 significant variables from case 1

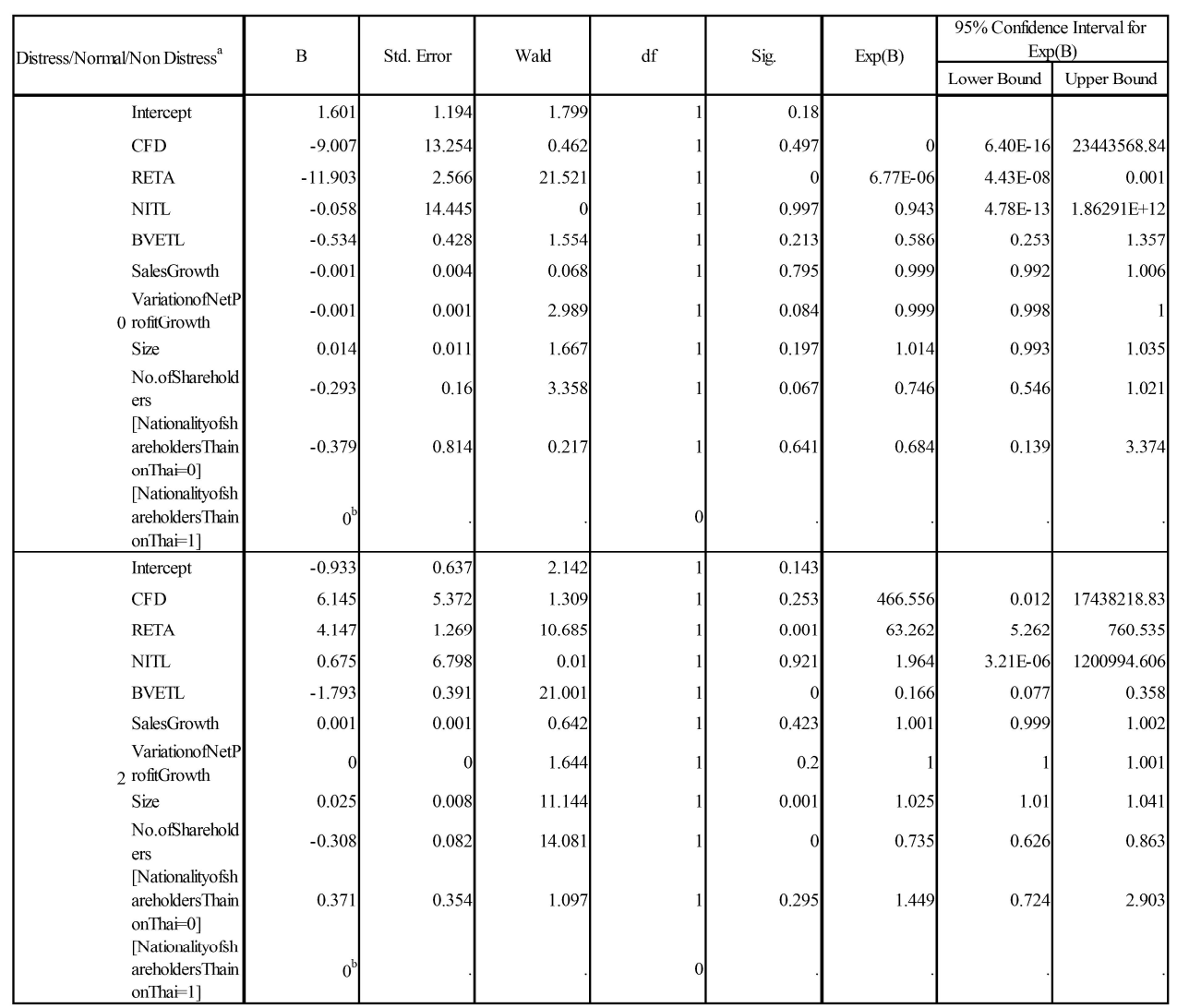

a. The reference category is: 1 .

b. This parameter is set to zero because it is redundant.

From table 4-5,

The Multinomial Regression Analysis models which is the Logistics model of long term financial health for logistics companies in Thailand are as follow.

Logit Response Function:

$$
g 0=L N\left(\frac{p 0}{p 1}\right)=-11.903(R E / T A)
$$




$$
\begin{aligned}
& g 2=L N\left(\frac{p 2}{p 1}\right)=-0.933+4.147(R E / T A)-1.793(B V E / T L)+0.025(\text { Size })- \\
& 0.308 \text { (No. of shareholder) }
\end{aligned}
$$

Where $g 0, g 2=\log$ odd or $\log i t$

$$
\begin{gathered}
g 1=0 \\
\pi_{j}(x)=\operatorname{Pr}(Y=j \mid x)=\frac{{ }_{e} g j(x)}{{ }_{e} g o(x)+1+{ }_{e} g^{2}(x)}
\end{gathered}
$$

Where $j=0$ to $2 \cdots$

$\operatorname{Pr}=$ Probability to the outcome of the interest

$\sum_{j=0}^{2} \operatorname{Pr}(Y=j \mid x)=1$

There are the estimated multinomial logistic regression coefficients for the models. In this study treats Normal group as the reference. Therefore, estimated a model for Distress (Unhealthy) relative to Normal and a model for Non-Distress (Healthy) relative to Normal. The parameter estimates are relative to Normal group.

For Distress (Unhealthy) relative to Normal.

1) The Wald test statistic for the variable RE/TA is 21.521 with an associated p-value of 0 . The study sets alpha level to 0.05 , means we would reject the null hypothesis and conclude that the regression coefficient for RETA has been found to be statistically different from zero for distress (unhealthy) to Normal given that other variables are in the model. In the other word, RE/TA is a significant variable in this group.

The other variables are failed to reject the null hypothesis and conclude that for the Unhealthy relative to Normal, the regression coefficient for the other variables have not been found to be statistically different from zero given that other variables are in the model. In the other word, other variables are not a significant variable in this group.

2) Intercept - For Thai companies (Nationality of shareholder $=1$ ), there is statistically uncertain whether they are more like to be classified as Non Distress (Healthy) or Normal.

3) From $B$, $\mathrm{RE} / \mathrm{TA}$ - if the company were to increase in RE/TA score by one point, the multinomial log-odds of Unhealthy would be expected to decrease by 11.903 unit while holding all other variables in the model constant. This may imply that the 
more retained earning higher than total asset, the chance to be in Unhealthy group is less.

4) From Exp (B), is the odds ratio for the predictors. The odds ratio of a coefficient indicates how the risk of the outcome falling in the comparison group compared to the risk of the outcome falling in the referent group changes with the variable in question.

RE/TA - The odds or "relative risk" ratio for a one unit increase in RE/TA score for Unhealthy to Normal level given that the other variables in the model are held constant. That means if the company increase RE/TA by one unit, the firm to be decreased by the factor of $6.77 \times 10^{-6}$ or less likely be in Unhealthy group.

For Non Distress group (Healthy) relative to Normal.

1) The Wald test statistic, RE/TA, BVE/TL, Size and No. of Shareholder are 10.685, 21.001, 11.144 and 14.081 respectively with an associated p-value of $0.001,0.00$, 0.001 and 0.00 . This means RE/TA, BE/TL, Size and No. of Shareholder are the significant variable in this group.

2) From $B$,

RE/TA - if the company were to increase in RE/TA score by one point, the multinomial log-odds of Healthy would be expected to increase by 4.147 unit while holding all other variables in the model constant. This may imply that the more retained earing higher than total asset, the chance to be in Healthy group is higher. $\mathrm{BVE} / \mathrm{TL}$ - if the company were to increase in BVE/TL score by one point, the multinomial log-odds of Healthy would be expected to decrease by 1.793 units while holding all other variables in the model constant. This may imply that the more booked value of equity higher than total liability the chance to be in Healthy group is less. Or Logistics Company should use the funds from liability to operate/expand the company more than using funds from shareholder.

Size - if the company were to increase in Size score by one unit, the multinomial log-odds of Healthy would be expected to increase by 0.025 units while holding all other variables in the model constant. This may imply that the higher the size the chance to be in Healthy group is higher.

No. of Shareholder - if the company were to increase in No. of Shareholder score by one unit, the multinomial log-odds of Healthy would be expected to decrease by 0.308 units while holding all other variables in the model constant. This may imply that the more shareholder the chance to be in Healthy group is less.

4) From $\operatorname{Exp}(B)$.

RE/TA and Size have odds ratio $>1$ that means if these variables increase by one 
unit, the relative risk for Healthy would be expected to increase by the factor of 63.262 and 1.025 respectively. RE/TA is the strongest drive for the company to be Healthy as highest $\operatorname{Exp}(\mathrm{B})$.

In contrast, BVE/TL and No. of Shareholder have odds ratio $<1$, that means if these variables increase by one unit, the relative risk for Healthy would be expected to decrease by 0.166 and 0.735 respectively.

The significant variables from Likelihood Ratio are RETA, BVETL, Size and No. of Shareholders which are the same variable as using Wald Statistics.

Case 2. Separate Analysis 5 significant Financial Variables from part I (case 1) that are $\mathrm{CF} / \mathrm{D}, \mathrm{RE} / \mathrm{TA}, \mathrm{BVE} / \mathrm{TL}$ and Sales Growth using MLRA. The parameter estimate is as follow.

Financial variables.

\section{Table 4-6.}

Parameter Estimates from MLRA for 5 significant financial variables from case 2

\begin{tabular}{|c|c|c|c|c|c|c|c|c|}
\hline \multirow{2}{*}{ Distress/Norma/Non Distress ${ }^{\mathrm{a}}$} & \multirow[t]{2}{*}{ B } & \multirow{2}{*}{ Std. Error } & \multirow{2}{*}{ Wald } & \multirow[t]{2}{*}{ df } & \multirow{2}{*}{ Sig. } & \multirow{2}{*}{$\operatorname{Exp}(B)$} & \multicolumn{2}{|c|}{$\begin{array}{c}95 \% \text { Confidence Interval for } \\
\text { Exp(B) } \\
\end{array}$} \\
\hline & & & & & & & Lower Bound & Upper Bound \\
\hline Intercept & -0.578 & 0.398 & 2.115 & 1 & 0.146 & & & \\
\hline CFD & -7.182 & 1.839 & 15.257 & 1 & 0 & 0.001 & $2.07 \mathrm{E}-05$ & 0.028 \\
\hline 0 RETA & -9.743 & 1.662 & 34.351 & 1 & 0 & $5.87 \mathrm{E}-05$ & $2.26 \mathrm{E}-06$ & 0.002 \\
\hline BVETL & -0.479 & 0.359 & 1.788 & 1 & 0.181 & 0.619 & 0.307 & 1.25 \\
\hline SalesGrowth & -0.001 & 0.003 & 0.113 & 1 & 0.737 & 0.999 & 0.992 & 1.006 \\
\hline Intercept & -1.585 & 0.265 & 35.676 & 1 & 0 & & & \\
\hline CFD & 4.068 & 0.795 & 26.191 & 1 & 0 & 58.444 & 12.306 & 277.559 \\
\hline 2 RETA & 0.31 & 0.641 & 0.234 & 1 & 0.629 & 1.363 & 0.388 & 4.785 \\
\hline BVETL & -0.424 & 0.103 & 16.952 & 1 & 0 & 0.654 & 0.534 & 0.801 \\
\hline SalesGrowth & 0.001 & 0.001 & 1.989 & 1 & 0.158 & 1.001 & 1 & 1.002 \\
\hline
\end{tabular}

a. The reference category is: 1 .

b. This parameter is set to zero because it is redundant.

From table 4-6,

The Multinomial Regression Analysis models which is the Logistics model of long term financial health for logistics companies in Thailand are as follow.

Logit Response Function:

From table parameter estimation, 


$$
\begin{aligned}
& g 0=L N\left(\frac{p 0}{p 1}\right)=-7.182(C F / D)-9.743(R E / T A) \cdots \cdots \cdots \cdots \\
& g 2=L N\left(\frac{p 2}{p 1}\right)=-1.585+4.068(C F / D)-0.424(B V E / T L)
\end{aligned}
$$

Where $g 0, g 2=\log$ odd or $\log i t$

$$
\begin{gathered}
g 1=0 \\
\pi_{j}(x)=\operatorname{Pr}(Y=j \mid x)=\frac{{ }_{e} g j(x)}{{ }_{e} g o(x)+1+{ }_{e} g^{2}(x)}
\end{gathered}
$$

Where $j=0$ to $2 \cdots$

$\operatorname{Pr}=$ Probability to the outcome of the interest

$\sum_{j=0}^{2} \operatorname{Pr}(Y=j \mid x)=1$

For Distress (Unhealthy) relative to Normal.

1) The Wald test statistic, CF/D and RE/TA are 15.257 and 34.351 with an associated p-value of 0 . The study sets alpha level to 0.05 , means $\mathrm{CF} / \mathrm{D}$ and RE/TA are significant variables in this group while the other variables are not statistically significant variables.

2) From $B$,

$\mathrm{CF} / \mathrm{D}$ - if the company has more cash flow to operate than debt, the chance to be in Unhealthy group is less.

RE/TA - the more retained earning higher than total asset, the chance to be in Unhealthy group is less.

4) From $\operatorname{Exp}(B)$,

$\mathrm{CF} / \mathrm{D}$ and $\mathrm{RE} / \mathrm{TA}$ have odds ratio $<1$ that means if these variables increase by one unit, the relative risk for Unhealthy would be expected to decrease by the factor of 0.001 and $5.87 \times 10-5$ respectively or the company more likely be in the Normal group.

For Non Distress group (Healthy) relative to Normal.

1) The Wald test statistic, CF/D and BVE/TL are 26.191 and 16.952 with an associated p-value of 0.000 . The study sets alpha level to 0.05 , means CF/D and $\mathrm{BVE} / \mathrm{TL}$ are significant variables in this group while the other variables are not statistically significant variables.

2) From $B$,

$\mathrm{CF} / \mathrm{D}$ - if the company has more cash flow to operate than debt, the chance to be in 
Healthy group is higher.

$\mathrm{BVE} / \mathrm{TL}$ - if the company were to increase in BVE/TL score by one point, the multinomial log-odds of Unhealthy would be expected to decrease by 0.424 units while holding all other variables in the model constant. This is the same result as case 1 which can confirm that Logistics Company should use the funds from liability to operate/expand the company more than using funds from shareholder.

3) From $\operatorname{Exp}(B)$.

$\mathrm{CF} / \mathrm{D}$ has odds ratio $>1$ that means if cash flow to debt ratio increases by one unit, the relative risk for Healthy would be expected to increase by the factor of 58.444 . The result is similar to case 1 that $C F / D$ is the strongest drive for the company to be Healthy BVE/TL has odds ratio $<1$ that means if this ratio increases by one unit, the relative risk for Healthy would be expected to decrease by the factor of 0.654 .

Among the 5 Variables, variable CFD and RETA are significant at the 0.05 level in Distress group, while, variable CFD and BVETL are significant at the 0.05 level for in Non-Distress group.

The significant variables from Likelihood Ratio are CFD, RETA and BVETL which are the same variable as using Wald Statistics. Pseudo R-Square from both Wald statistics and Likelihood ratio are the same. 


\section{$\underline{\text { Non-Financial variables }}$}

Table 4-7.

Parameter Estimates from MLRA for 5 significant Non-Financial variables from case 2

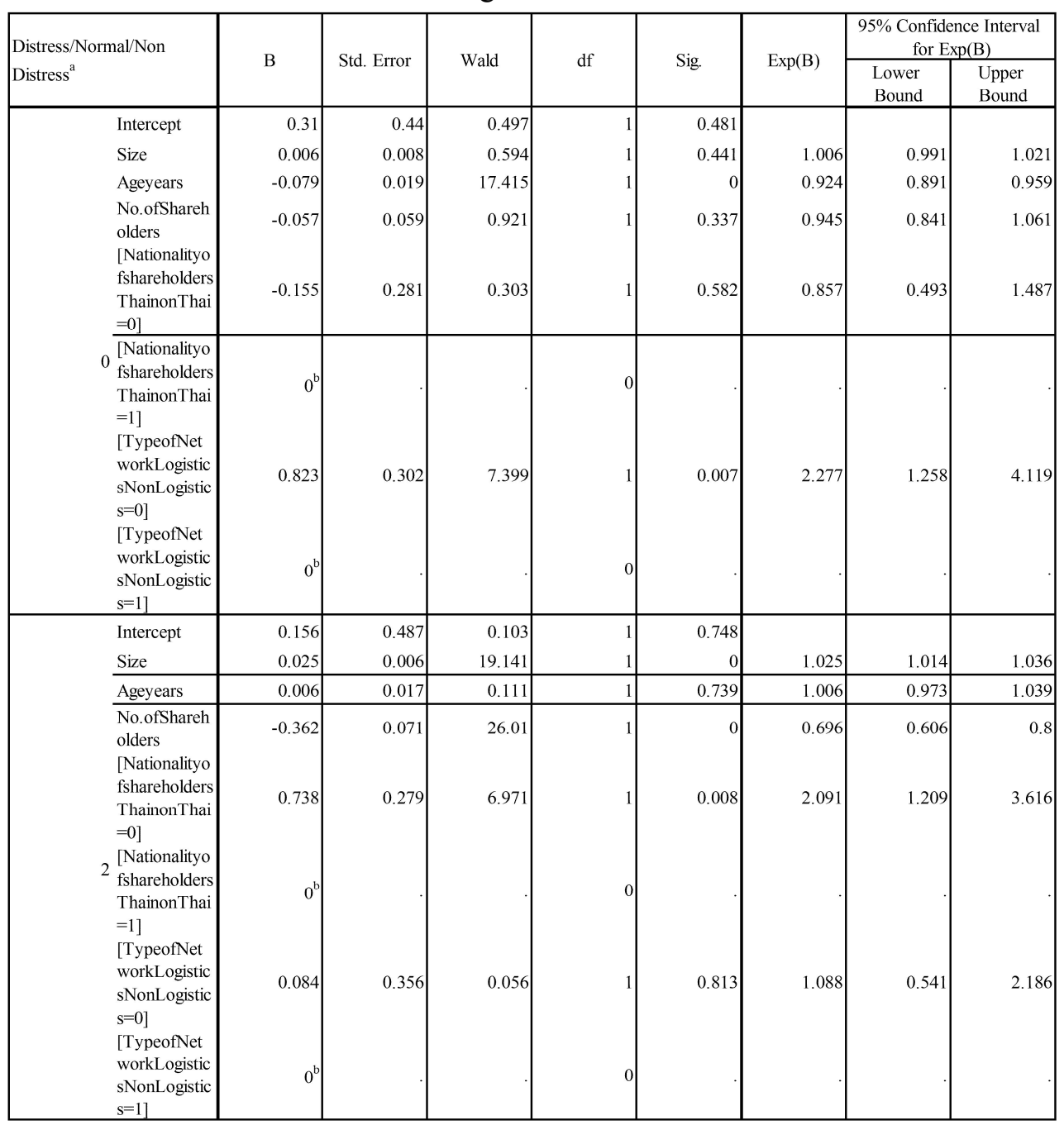

From table parameter estimation,

$g 0=L N\left(\frac{p 0}{p 1}\right)=-0.079($ Age $)+0.823($ Type of Network $)$ 
$g 2=L N\left(\frac{p 2}{p 1}\right)=$

0.025 (Size) - 0.362(No. of Shareholders $)+0.738$ (Nationality of Shareholders $)$

Where $g 0, g 2=\log$ odd or $\log i t$

$$
g 1=0
$$

$\pi_{j}(x)=\operatorname{Pr}(Y=j \mid x)=\frac{e^{g j(x)}}{{ }_{e} g o(x)+1+{ }_{e} g^{2}(x)}$

Where $j=0$ to $2 \cdots$

$\operatorname{Pr}=$ Probability to the outcome of the interest

$\sum_{j=0}^{2} \operatorname{Pr}(Y=j \mid x)=1$

For Distress (Unhealthy) relative to Normal.

1) The Wald test statistic for the variable Age and Type of Network are 0.497 and 7.399 with an associated p-value of 0 . The study sets alpha level to 0.05 , means Age and Type of Network are significant variables in this group while the other variables are not statistically significant variables.

2) From $B$,

Age - if the age of company were to increase in by one unit, the multinomial log-odds of Healthy would be expected to decrease by 0.079 units while holding all other variables in the model constant. This may imply that the young company has higher chance to be in Unhealthy group.

Type of Network - company has non logistics Network is more likely to be in Unhealthy group than company has logistics Network.

3) From $\operatorname{Exp}(B)$,

Age have odds ratio $<1$ that means if age increase by one unit, the relative risk for Unhealthy would be expected to decrease by the factor of 0.924 .

Type of Network have odds ratio $>1$ that means if these variables increase by one unit, the relative risk for Unhealthy would be expected to increase by the factor of 2.277 respectively. Or company with non-logistic network is likely to be in the Unhealthy group.

For Non Distress group (Healthy) relative to Normal.

1) The Wald test statistic, Size, No. of Shareholder and Nationality of Shareholder are 19.14, 26.010 and 6.971 with an associated p-value of $0.000,0.00$ and 0.018 respectively. The study sets alpha level to 0.05 , means Size, No. of Shareholder and Nationality of Shareholder are significant variables in this group while the other 
variables are not statistically significant variables.

2) From $B$,

Size - if the company were to increase in Size score by one unit, the multinomial log-odds of Healthy would be expected to increase by 0.025 units while holding all other variables in the model constant. This may imply that the higher the size the chance to be in Healthy group is higher (same as case 1)

No. of Shareholder - if the company were to increase in No. of Shareholder score by one unit, the multinomial log-odds of Healthy would be expected to decrease by 0.362 units while holding all other variables in the model constant. This may imply that the more shareholder the chance to be in Healthy group is less. (Same as case 1) Nationality - Non Thai company (International company) relative to Thai company given the other variables are constant is 0.738 unit higher for Healthy group. Or International Company is more likely to be in Healthy group.

4) From $\operatorname{Exp}(B)$.

Size and Nationality have odds ratio $>1$ that means if these variables increase by one unit, the relative risk for Healthy would be expected to increase by the factor of 1.025 and 2.091 respectively. Nationality of Shareholder is the strongest drive for the company to be Healthy as highest $\operatorname{Exp}(\mathrm{B})$.

In contrast, No. of Shareholder has odds ratio $<1$, that means if these variables increase by one unit, the relative risk for Healthy would be expected to decrease by 0.696 .

The significant variables from Likelihood Ratio are Age, Size, No. of Shareholders, Nationality of Shareholders and Type of Network which are the same variable as using Wald Statistics. Conclusion table from the analysis is as follow.

Table 4-8.

Summary of MLRA results (Part II)

\begin{tabular}{|c|c|c|c|c|c|c|c|c|c|c|c|c|c|}
\hline \multirow[b]{2}{*}{ Variables } & \multirow[b]{2}{*}{ Groups } & \multirow{2}{*}{\begin{tabular}{|c|}
$\begin{array}{c}\text { Liquidity } \\
\text { Ratio }\end{array}$ \\
CF/D \\
\end{tabular}} & \multirow{2}{*}{\begin{tabular}{|c|} 
Profitabilit \\
$y$ Ratio
\end{tabular} \mid} & \multicolumn{2}{|c|}{ verage Ratio } & \multirow[t]{2}{*}{$\begin{array}{c}\text { Efficie } \\
\text { ncy } \\
\text { Ratio }\end{array}$} & \multirow[t]{2}{*}{$\begin{array}{l}\text { Sales } \\
\text { Growth }\end{array}$} & \multirow[t]{2}{*}{$\begin{array}{l}\text { Variation } \\
\text { of Net } \\
\text { profit } \\
\text { growth }\end{array}$} & \multirow[t]{2}{*}{ Size } & \multirow[t]{2}{*}{ Age } & \multirow[t]{2}{*}{$\begin{array}{c}\text { Nationalit } \\
\text { y of } \\
\text { Sharehold } \\
\text { ers }\end{array}$} & \multirow[t]{2}{*}{$\begin{array}{l}\text { Type of } \\
\text { Network }\end{array}$} & \multirow[t]{2}{*}{$\begin{array}{c}\text { No. of } \\
\text { sharehold } \\
\text { ers }\end{array}$} \\
\hline & & & & $\mathrm{NI} / \mathrm{TL}$ & $\mathrm{BVE} / \mathrm{TL}$ & & & & & & & & \\
\hline \multirow[b]{2}{*}{ All 9 variables } & Distress & & -11.903 & & & & & & & & & & \\
\hline & Non Distress & & 4.147 & & -1.793 & & & & $2.50 \mathrm{E}-02$ & & & & -0.308 \\
\hline \multirow[b]{2}{*}{5 Financial variables } & Distress & -7.182 & -9.741 & & & & & & & & & & \\
\hline & Non Distress & 4.068 & & & -0.424 & & & & & & & & \\
\hline \multirow{2}{*}{$\begin{array}{c}5 \text { Non Financial } \\
\text { variables }\end{array}$} & Distress & & & & & & & & & -0.079 & & 0.823 & \\
\hline & Non Distress & & & & & & & & $2.50 \mathrm{E}-02$ & & 0.738 & & -0.362 \\
\hline
\end{tabular}




\section{Conclusion}

The study found out that factors determine long term financial stability for Logistics companies in Thailand are CFD, RETA, BVETL, Size, Age, Nationality of Shareholder, Type of network and No. of Shareholder. From case 1 (Applying total 23 variables (Financial Variables and Nonfinancial Variables) at the same time. The following characters will drive the company to have more chance to be healthy company; high retained earing than total asset, using funds from liability instead of funds from equity, higher register capital, and have less number of shareholders. RETA is the strongest impact on the long terms stability of financial health. From case 2 (Applying Financial Variables separate from Non-Financial Variables), apart from the same result from case 1, there are cash flow higher than debt and being International Company will drive the company to have more chance to be in Healthy company. By far, case 2, the CFD is the strongest impact on the long term stability of financial health. On the other hands, Young Company and company without logistics network have higher chance to be unhealthy company.

RETA and CFD are positive drivers for improving both "from Distress (Unhealthy) to Normal" and "from Normal to Non-distress (Healthy)" but they seem to be more effective for "from Distress (Unhealthy) to Normal". BVE/TL is a negative driver "from Normal to Non-distress (Healthy)". This implies that "debt financing" is not bad for financial health. Number of shareholders is also a negative driver for "from Normal to Non-distress (Healthy)" while Foreign Participation is a positive driver for "from Normal to Non-distress (Healthy)".

From the research, company's financial health is also influenced by its corporate governance mechanism. 


\section{References}

Aas, T. H., \& Pedersen, P. E., 2011. The impact of service innovation on firm-level financial performance. The Service Industries Journal, 31(13), 2071-2090.

Aasen, M. R., 2011. Applying Altman's Z-Score to the Financial Crisis: an empirical study of financial distress on Oslo Stock Exchange.

Agarwal, V., \& Taffler, R., 2007. Twenty-five years of the Taffler z-score model: Does it really have predictive ability? Accounting and Business Research, 37(4), 285-300.

Almajali, A. Y., Alamro, S. A., \& Al-Soub, Y. Z., 2012. Factors Affecting the Financial Performance of Jordanian Insurance Companies Listed at Amman Stock Exchange. Journal of Management Research, 4(2).

Altman, E. I., 1984. The success of business failure prediction models: An international survey. Journal of Banking and Finance, 8(2), 171-198.

Altman, E. I., Haldeman, R. G., \& Narayanan, P., 1977. ZETA TM analysis A new model to identify bankruptcy risk of corporations. Journal of Banking and Finance, 1(1), 29-54.

Altman E.I.et al., 2014. Distress firms and Bankruptcy prediction in an internatioinal context: a review and empirical analysis of Altman's Z-Score Model. Journal of Accounting and Corporate Governance, 1(2), 1-13.

Amal Yassin, A., Sameer Ahmed, A., \& Yahya Zakarea, A.-s., 2012. Factors Affecting the Financial Performance of Jordanian Insurance Companies Listed at Amman Stock Exchange. Journal of Management Research, 4(2), 266.

Bahaaeddin Ahmed, A., \& Joel, B., 2012. Predicting Listed Companies' Failure in Jordan Using Altman Models: A Case Study. International Journal of Business and Management, 8(1). 
Bandyopadhyay, A., 2006. Predicting probability of default of Indian corporate bonds: logistic and Z-score model approaches. Journal of Risk Finance, $7(3), 255$.

Birch, R., 2010. New Credit Decision Model Projects Borrowers' Future Financial Health. Credit Union Journal, 14(7), 3.

Cestari, G., Risaliti, G., \& Pierotti, M., 2013. Bankruptcy prediction models: preliminary thoughts on the determination of parameters for the evaluation of effectiveness and efficiency. European Scientific Journal, 9(16), 265.

Charitou, A., Neophytou, E., \& Charalambous, C., 2004. Predicting corporate failure: empirical evidence for the UK. European Accounting Review, 13(3), 465-497.

Chieh-Yu, L., 2007. Factors affecting innovation in logistics technologies for logistics service providers in China. Journal of Technology Management in China, 2(1), 22-37.

Clark, K. B., 1982. Unionization and Firm Performance: The Impact on Profits, Growth and Productivity. Cambridge, Mass., USA.

Collins, R. A., \& Green, R. D., 1982. Statistical methods for bankruptcy forecasting. Journal of Economics and Business, 34(4), 349-354.

Cui, L. G., Su, S. L. I., \& Hertz, S., 2012. Logistics Innovation in China. Transportation Journal, 51(1), 98-117.

D'Avanzo, R., Von Lewinski, H., \& Van Wassenhore, L. N., 2003. The link between supply chain and financial performance.(Growth). Supply Chain Management Review, 7(6), 40.

Dawley, D. D., Hoffman, J. J., \& Brockman, E. N., 2003. Do size and diversification type matter? An examination of post-bankruptcy outcomes. Journal of Managerial Issues, 15(4), 413. 
Donker, H., Santen, B., \& Zahir, S., 2009. Ownership structure and the likelihood of financial distress in the Netherlands. Applied Financial Economics, 19(21), 1687-1696.

Donnelly, G., 2005. A budget model to determine the financial health of nursing education programs in academic institutions. Nursing leadership forum, 9(4), 143.

Dossi, A., \& Patelli, L., 2010. You Learn From What You Measure: Financial and Non-financial Performance Measures in Multinational Companies. Long Range Planning, 43(4), 498-526.

Edward, I. A., \& James, K. L. F., 1981. Managing a return to financial health. Journal of Business Strategy, 2(1), 31-38.

Eidleman, G. J., 1995. Z scores - a guide to failure prediction. (business failure) (Auditing). The CPA Journal, 65(2), 52.

Ellinger, A. E., Lynch, D. F., \& Hansen, J. D., 2003. Firm size, web site content, and financial performance in the transportation industry. Industrial Marketing Management, 32(3), 177-185.

Erkki, K. L., 2005. Survival Analysis and Financial Distress Prediction\&colon Finnish Evidence. Review of Accounting \& Finance, 4(4), 76-90.

Forker, L. B., 1997. Factors affecting supplier quality performance. Journal of Operations Management, 15(4), 243-269.

González-Bravo, M. I., \& Mecaj, A., 2011. Structural and Evolutionary Patterns of Companies in a Financial Distress Situation. Advances in Decision Sciences, 2011.

Hanzaee, A. H., 2010. Test of the generalizability of Altman's bankruptcy predication model (pp. 215-250).

He, Y., \& Kamath, R., 2005. Bankruptcy Prediction of Small Firms in an Individual Industry with the Help of Mixed Industry Models. Asia-Pacific Journal of Accounting \& Economics, 12(1), 19-36. 
Hendricks, K. B., \& Singhal, V. R., 2003. The effect of supply chain glitches on shareholder wealth. Journal of Operations Management, 21(5), 501-522.

Hu Gang, H. G., \& Zhang Xiaomao, Z. X., 2009. Study on Improving Z-score Model Based on the Logistic Model: Evidence from Listed Companies in China (Vol. 2, pp. 240-244).

Karia, N., \& Wong, C. Y., 2012. The impact of logistics resources on the performance of Malaysian logistics service providers. Production Planning \& Control, 24(7), 589-606.

Khalid, A., \& Ahmad Eqab Al, B., 2011. Predicting Corporate Bankruptcy of Jordanian Listed Companies: Using Altman and Kida Models. International Journal of Business and Management, 6(3).

Khunthong J., 1998. Red Flags on Financial Failure : The case of Thai Corporation. A Doctoral Dissertation for the Joint Doctoral Business Administration Program (JDBA)

Kingsley Opoku, A., \& Joshua, A., 2009. Predicting corporate failure: some empirical evidence from the UK (Vol. 16, pp. 432-444): Emerald Group Publishing Limited.

Kotabe, M., \& Mol, M. J. (2009). Outsourcing and financial performance: A negative curvilinear effect. Journal of Purchasing and Supply Management, 15(4), 205-213.

Kožená, M., \& Chládek, T., 2012. Company Competitiveness Measurement Depending on its Size and Field of Activities. Procedia - Social and Behavioral Sciences, 58, 1085-1090.

Kun, L., Erika, M., Eldon, J., \& Ying, L., 2011. Global supply chain adaptations to improve financial performance

Supply base establishment and logistics integration. Journal of Manufacturing Technology Management, 22(2), 204-222. 
Lähtinen, K, \& Toppinen, A., 2008. Financial performance in Finnish large- and medium-sized sawmills: The effects of value-added creation and cost-efficiency seeking. Journal of Forest Economics, 14(4), 289-305.

Levine, R., 2000. New business model boosts financial health of insurer. Puget Sound Business Journal, 21(7), 77.

Li Sui-cheng, L. S.-c., Lin Jun, L. J., \& Yin Hong-ying, Y. H.-y., 2006. Research on the Factors Influencing Stability of the Supply Chain Cooperation Relationships (pp. 657-662).

Lupu, D., \& Onofrei, M., 2012. Controversies regarding the utilization of Altman model in Romania. Controversies regarding the utilization of Altman model in Romania(1), 33-42.

Mao, Z., \& Gu, Z., 2008. The Relationship Between Financial Factors and Firm Performance: Empirical Evidence from U.S. Restaurant Firms. Journal of Foodservice Business Research, 11(2), 138-159.

Metlik, D., Jakobsson, S., Scheutz, C., Smolander, M., Millak, J., \& Wague, C., 2011. Konkurser utan gränser?: En utvärdering av Altmans $Z^{\prime}$-scoremodell på företag i Sverige Bankruptcy without borders?: An Evaluation of Altman's Z'-Score Model for Companies in Sweden.

Mine, U., \& Hakan, A., 2006. Prediction of corporate financial distress in an emerging market: the case of Turkey (Vol. 13, pp. 277-295): Emerald Group Publishing Limited.

Monti, N. E., \& Garcia, R. M., 2010. A statistical analysis to predict financial distress.(Report). Journal of Service Science and Management (JSSM), 3(3), 309.

Nguyen Ngoc, D., \& Nguyen Anh, P., 2013. The Factors Effect to the Financial Efficiency of FDI (Foreign Direct Investment) Enterprises Located in Ho Chi Minh City-Viet Nam. Asian Economic and Financial Review, 3(6), 703. 
Nicolas Emanuel, M., \& Roberto Mariano, G., 2010. A Statistical Analysis to Predict Financial Distress. Journal of Service Science and Management, 03(03), 309.

Pitrova, K., 2011. Possibilities of the Altman zeta model application to Czech firms.(EKONOMIKA A MANAGEMENT). E+M Ekonomie a Management(3), 66.

Qian Guo-ming, Q. G.-m., Feng Yuan, F. Y., \& Zhou Ling, Z. L., 2007. Financial Distress Prediction Models of China's Listed Companies (pp. 1824-1829).

Ohlso, J.S., 1980. Financial Ratios and the Probabilistic Prediction of Bankruptcy. Journal of Accounting Research (spring), 109-131.

Rabo, J. S. , 2008. Make Haste or Waste: A Case Study on Predicting Bankruptcy of Weyst Oyl Corporation Using Altman's Z-Score Model. DLSU Business \& Economics Review, 17(1), 85-97.

Shen, J. , 2006. Factors affecting international staffing in Chinese multinationals (MNEs). The International Journal of Human Resource Management, 17(2), 295-315.

Shuk-Wern, O., Voon Choong, Y., \& Roy, W. L. K., 2011. Corporate failure prediction: a study of public listed companies in Malaysia. Managerial Finance, 37(6), 553-564.

Sohn, S. Y., Kim, H. S., \& Moon, T. H. , 2007. Predicting the financial performance index of technology fund for SME using structural equation model. Expert Systems with Applications, 32(3), 890-898.

Soliman, M. T. , 2008. The use of DuPont analysis by market participants. The accounting review : a journal of the American Accounting Association, 83(3), 823-853.

Suhaimi, R., Abdullah, F., \& Saban, G. , 2010. Factors affecting profit efficiency of commercial banks in Malaysia (pp. 1059-1064). 
Thomas Ng, S., Wong, J. M. W., \& Zhang, J. , 2011. Applying Z-score model to distinguish insolvent construction companies in China. Habitat International, 35(4), 599-607.

Tippayawong, K. Y., Patitad, P., Sopadang, A., \& Enkawa, T., 2010. Factors affecting efficient supply chain operational performance of high and low technology companies in Thailand.(Report). Management Science and Engineering, 4(3), 24.

Wang, Y. , 2010. Business failure prediction for publicly listed companies in China. Journal of business and management : JBM, 16(1), 75-88.

Wang Zhi-ning, W. Z.-n., \& Wu Ying-yu, W. Y.-y., 2010. Financial Distress Prediction of China Listed Companies Based on SD Model and LSSVM (pp. 1532-1535).

Wu, Y., Gaunt, C., \& Gray, S., 2010. A comparison of alternative bankruptcy prediction models. Journal of Contemporary Accounting \& Economics, 6(1), 34-45. 